\title{
Ekologia pejzażu dźwiękowego
}

\author{
Magdalena Szpunar \\ Uniwersytet Jagielloński \\ m.szpunar@uj.edu.pl
}

Przyjęto 1 grudnia 2019; zaakceptowano 20 września 2020; opublikowano 19 grudnia 2020.

\begin{abstract}
Abstrakt
W artykule autorka stawia tezę, iż w tym, jak słyszymy i co słyszymy, zawiera się klucz do zrozumienia kondycji współczesnego człowieka. Kulturę i nasze społeczne otoczenie odbieramy głównie wzrokowo, a dominujący wzrokocentryzm sprawia, że słyszenie staje się dla nas wtórne i mało znaczące, stąd pojawia się potrzeba kontestacji takiej wzrokocentrycznej hegemonii, ograniczonej do jednego zmysłu. Artykuł mieści się w ramach nurtu soundscape studies, który analizuje dźwięk jako istotny zasób środowiska, zarzewie znaczeń i doświadczeń estetycznych. Szczególne miejsce w tekście poświęcone zostało przemianom, zachodzącym w krajobrazie dźwiękowym, zmieniającym się funkcjom dźwięku, a także pozytywnemu wpływowi krajobrazu (w tym dźwiękowego) na dobrostan psychiczny człowieka.
\end{abstract}

Słowa kluczowe: pejzaż dźwiękowy; antropocen; dźwięk; soundscape studies; cisza; hałas; audiosfera; fonosfera

\section{Wprowadzenie}

W tym, jak słyszymy i co słyszymy, zawiera się klucz do zrozumienia kondycji współczesnego człowieka. Proces poznawania świata wymaga od nas wysiłku i zaangażowania, większość z nas odrzuca podejmowanie jakiejkolwiek aktywności poznawczej (Welsch, 1997; Carter i in., 2014) ${ }^{1}$, raczej rozwijając w sobie zdolności przeciwne - ,aby patrząc - nie widzieć, aby słuchając - nie słyszeć" (Kapuściński, 2004, s. 252). Funkcjonujemy w społeczeństwach „wysokich prędkości” (Rosa, 2003), które sprawiają, że nasze działania mają coraz częściej

\footnotetext{
${ }^{1}$ Wolfgang Welsch (1997) wyraźnie wskazywał, iż przychodzi nam żyć w czasach desensytyzacji, anestezji, w których odwrażliwiamy się na doznawane bodźce, ale i coraz słabiej odczuwamy. Zgodnie z logiką Welschowskiej anestetyki, nadmiarowość docierających do nas zewsząd bodźców sprawia, że stajemy się na nie obojętni, „odwrażliwiamy się” na nie. Inaczej ujmując, możemy powiedzieć, iż nadmiarowość obrazów implikuje ich percepcyjną śmierć. W jednym ze swoich artykułów (Szpunar, 2017a) stawiam hipotezę, iż proces desensytyzacji nie ogranicza się do sfery wizualności, odwrażliwieniu ulegamy w ogóle, będąc nieczułym nie tylko na bodźce, ale także na innych ludzi.
} 
charakter zautomatyzowany, rutynowy, bezrefleksyjny, a głównym naszym celem staje się maksymalna efektywność (zob. Szpunar, 2019, s. 95-104). Konsekwencją życia w społeczeństwach wysokich prędkości jest wzrost poczucia braku satysfakcji z życia, czy też - posiłkując się kategorią Mihalyego Csikszentmihalyi - umysłowej entropii ${ }^{2}$. Guy Debord wieścił dotknięcie współczesnych społeczeństw „powszechnym autyzmem” (2006, s. 143). Jego zdaniem, kontakty międzyludzkie stają się jedynie iluzją spotkania, a uwagę ludzi bardziej zaprzątają towary niż autentyczne relacje. Potwierdzając intuicje Deborda, Andrzej Leder (2000; 2006) przekonuje, że w wieku XXI będziemy mieć do czynienia ze stanem, który określić można jako autyzm kulturowy. Fragmentaryzacja sfery publicznej, kurczenie się sfery symbolicznej oraz hegemonia myślenia pierwszoosobowego sprawia, że autyzm kulturowy staje się faktem społecznym. W takiej optyce intersubiektywne komunikowanie staje się coraz trudniejsze, gdyż nie wiadomo, do kogo lub czego można się odwołać, by odnaleźć wspólną przestrzeń symbolicznego porozumienia.

Jak wskazywał Wolfgang Welsch, kulturę i nasze społeczne otoczenie odbieramy głównie wzrokowo, a dominujący wzrokocentryzm ${ }^{3}$ sprawia, że słyszenie staje się dla nas wtórne i mało znaczące. Niemiecki filozof sprzeciwiał się takiej wzrokocentrycznej hegemonii ograniczonej do jednego zmysłu. W swoim eseju o kulturze słyszenia pisał (Welsch, 2001, s. 56):

na przetrwanie ludzkiego gatunku oraz planety Ziemi można mieć tylko wtedy nadzieję, kiedy nasza kultura przyjmie słyszenie jako zasadniczy wzór, dawna bowiem dominacja widzenia prowadzi nas w stechnicyzowanej modernie wprost ku katastrofie, przed którą może nas ustrzec receptywno-komunikatywno-symbiotyczny stosunek do świata słuchu. Zagłada lub ratunek, katastrofa lub ozdrowienie - oto alternatywny scenariusz, którym próbuje się nami wstrząsnąć, byśmy otworzyli uszy.

Wydaje się zatem, że w sposób uprawniony można mówić o konieczności dokonania się zwrotu audialnego na wzór ikonograficznego, performatywnego czy pamięciowego 4 .

Pod koniec wieku XVIII podróżowano celem poszukiwania genius loci, miejsc, widoków i nastrojów, które przenoszą w inny czas, pozwalają zdystansować się od codzienności (por. Urry, 2007). W ostatnim czasie rosnącą popularnością cieszy się „turystyka akustyczna”, która ogniskuje się na słuchowym pozwaniu miejsc i regionów, odkrywaniu przestrzeni posiadających unikalne właściwości akustyczne (Braden, 2012; Bernat, 2017). Jak pokazują

\footnotetext{
${ }^{2}$ Zaczerpnięta z fizyki kategoria entropii oznacza nieuporządkowanie układu. W układach, w których zmiany mają charakter samoistny, rośnie entropia, a wraz z nią chaos (zob. Csikszentmihalyi, 2005).

${ }^{3}$ Wielu badaczy kultury współczesnej zwraca uwagę na dokonujący się ,zwrot piktorialny”. Dominacja obrazu nad słowem jest coraz wyraźniej widoczna, czego przykładem jest rozkwit takich subdyscyplin, jak socjologia wizualna czy antropologia obrazu. Już w 1992 roku William J. Mitchell (1994) ukuł pojęcie ,zwrotu piktorialnego", rozumiejąc pod nim znaczące przemieszczenie, które zasadza się w tym, iż już nie język, a wizualność jest tym, co organizuje funkcjonowanie mediów.

${ }^{4}$ Problematyce tej został poświęcony numer specjalny kwartalnika „Kultura Współczesna”, zatytułowany Muzyka w kulturze. Kultura w muzyce”, nr 3/2017, redagowany przez Magdalenę Szpunar i Magdalenę Parus, w którym czytelnik odnajdzie szerokie omówienie tej problematyki.
} 
badania, wspomnienia podróżujących odwołują się głównie do krajobrazu, ale co ciekawe, dość duże znaczenie przypisywane jest dźwiękom (Kulczyk, 2013).

Tereny miejskie stały się przestrzenią, w której przyjazne człowiekowi dźwięki natury, zostały wyparte przez dojmujący hałas uprzemysłowionego miasta. W przeszłości dźwięki pełniły funkcje informacyjne, ostrzegawcze, determinowały rozmieszczenie ludzkich osad i podtrzymywały relacje. Wrażliwość sensualna ludzi przynależących do społeczności tradycyjnych, potrafiących różnicować wielość sygnałów emitowanych przez przyrodę (Myśliwski, 2000), została zastąpiona desensytyzacją człowieka miasta, który słuchając nie słyszy, a patrząc nie widzi (por. Szpunar, 2018a). Hałas cywilizacyjny zaliczany jest do głównych przyczyn obniżania się jakości życia (Pawlas, 2015; Kryter, 1970). W partycypowaniu świata i rzeczywistości cisza stała się kategorią właściwie nieobecną. Cisza, utożsamiana z możliwością słyszenia dźwięków natury, staje się wartością niezwykle pożądaną i poszukiwaną (Bernat, 2011, s. 195) przez przeciążonego hałasem człowieka. W tym kontekście ochrona zanikających, naturalnych krajobrazów dźwiękowych staje się kluczowym wyzwaniem w obszarze ochrony dziedzictwa przyrodniczego. Doświadczanie krajobrazu związane jest nie tylko z oczywistymi, wizualnymi aspektami przestrzeni, ale także mniej dosadnymi - dźwiękami i zapachami, które wpływają na jego ewaluację. Inaczej ujmując, holistyczna percepcja świata nie jest możliwa $\mathrm{z}$ pominięciem czynnika akustycznego.

\section{Antropocen jako epoka dominacji człowieka}

Zwrócenie uwagi na ochronę ciszy, pejzaży dźwiękowych charakteryzujących się małą odpornością na zmiany antropogeniczne, należy do kluczowych wyzwań XXI wieku. Pod koniec XX wieku w dyskursie naukowym pojawiła się nowa kategoria pojęciowa antropocenu. Pod terminem tym rozumie się epokę geologiczną, która zdominowana jest działalnością człowieka (Stoner, Melathopoulos, 2015; Bińczyk, 2018), inaczej ujmując, jest epoką totalizującego władztwa człowieka. Za twórcę tego terminu uznaje się laureata Nagrody Nobla w dziedzinie chemii Paula Crutzena (Malm, Hornborg, 2014), który zwracał uwagę na ogromny wpływ człowieka na procesy przyrodnicze. Badacze tego procesu jednoznacznie wskazują, że wpływ homo sapiens na atmosferę, litosferę oraz hydrosferę jest bezprecedensowy, a od momentu rewolucji przemysłowej niezwykle intensywny (Castree, 2014). Epoka antropocenu przejawiać się ma przede wszystkim w gwałtownych procesach urbanizacji, zanieczyszczenia środowiska, wyczerpywania paliw kopalnych czy emisji gazów cieplarnianych (Steffen, Broadgate, Gaffney, 2015). Uznaje się za konieczne posiłkowanie się kategorią antropocenu, gdyż mamy do czynienia z postępującym procesem urbanizacji, degradacji gleb, zakwaszeniem oceanów, zaburzeniem cykli biochemicznych Ziemi, a także utratą bioróżnorodności ${ }^{5}$. Polska badaczka tego fenomenu, Ewa Bińczyk uznaje antropocen za epokę, która określa człowieka jako aktywnego aktora procesów geologicznych (Bińczyk,

\footnotetext{
${ }^{5}$ W literaturze pojawia się kategoria „szóstej katastrofy” (Kolbert, 2014). Zwraca się uwagę, iż rocznie wymiera około 40 tysięcy różnych gatunków (Kubicki, 1994); istnieją także szacunki, mówiące o wymieraniu od 5000 do 500000 organizmów żywych rocznie (Dobrzański, Dobrzańska, Kiełczewski, 1997), a owo masowe wymieranie tłumaczy się ekspansywną działalnością człowieka.
} 
2018). Przy tym, zwrócić należy uwagę, iż choć propozycja posiłkowania się kategorią antropocenu wyszła od przedstawicieli nauk ścisłych, to w humanistyce dyskusja na ten temat toczy się od dłuższego czasu ${ }^{6}$ (por. Domańska, 2008; Szpunar, 2016).

Zwolennicy antropocentryzmu umieszczają jednostkę ludzką w centrum zainteresowań badawczych, uznając prymat człowieka i tego, co ludzkie nad innymi aktorami, w tymi nieludzkimi, takimi jak chociażby przyroda. Bińczyk (2018) wyróżnia cztery podstawowe wymiary antropocentryzmu: poznawczy, który oznacza „konieczność” przyjmowania perspektywy ludzkiej, niezależnie od specyfiki danej sytuacji, ontologiczny, który przyznaje człowiekowi uprzywilejowaną pozycję w hierarchii bytów, metodologiczny oznacza koncentrowanie się na sprawczej roli człowieka, przy jednoczesnym ingerowaniu bytów pozaludzkich, zaś aksjologiczny mówi o wartościach ludzkich jako nadrzędnych i bezdyskusyjnych.

Postulaty o konieczności dokonania zwrotu post-antropocentrycznego, konieczności odejścia w myśleniu o człowieku jako mierze wszechrzeczy i nadrzędnej wobec wszystkich istot kategorii są w nauce obecne coraz wyraźniej (Domańska, 2008; Domańska, 2010; Szostek, 2014; Markiewicz, 2015; Keating, Merenda, 2013). Ekosprawiedliwość jest dzisiaj nie tyle ekscentryzmem, co koniecznością, chroniącą nas przed ekologiczną zagładą. Przedstawiciele wielu dyscyplin głoszą konieczność ekologizowania humanistyki (Domańska, 2013; Tyburski, 2013; Bińczyk, 2018) czy wprowadzenia ekologii politycznej, celem zapewnienia stabilnej przyszłości zbiorowości, nie tylko ludzkich, ale także rozlicznych aktorów pozaludzkich ${ }^{7}$. W spopularyzowanym za sprawą Bruno Latoura $(2009 ; 2010)$ nurcie ANT (ActorNetwork Theory) aktorzy pozaludzcy są ujmowani jako równoprawni aktorzy życia społecznego (por. Abriszewski 2007; 2008; 2010).

\section{Denializm klimatyczny}

Nietrudno zauważyć, że dyskurs wokół degradacji środowiska charakteryzuje swoista bezradność, a nawet wyparcie, tworzące swoisty denializm klimatyczny. Denializm klimatyczny jest niczym innym jak konglomeratem psychologicznych mechanizmów zaprzeczenia $^{8}$, negowania faktów dotyczących zmiany klimatu, podważania ingerującej i dewastującej roli człowieka (Powell, 2012). Ludzie od początku dziejów obawiali się czegoś

\footnotetext{
${ }^{6}$ Ewa Domańska uznaje, że należy współcześnie mówić o de-antropocentryzacji humanistyki. Oznacza ona nie tyle eliminowanie człowieka jako podmiotu badań, ale uznanie, że niekoniecznie człowiek jest miarą wszechrzeczy, co wydaje się być koniecznością w dobie inżynierii genetycznej, psychofarmakologii czy nanotechnologii.

${ }^{7} \mathrm{~W}$ polskich thumaczeniach terminu nonhuman actors pojawiają się dwa jego rozumienia. Agata Czarnacka proponuje termin „aktorzy nie-ludzcy” (Latour, 2009), zaś Krzysztof Abriszewski posługuje się terminem „aktorzy poza-ludzcy” (Latour, 2010). Wielu autorów postuluje, by operować terminem zaproponowanym przez Abriszewskiego, który nie posiada wartościującego charakteru, jak tłumaczenie Czarnackiej.

8 Zaprzeczenie stanowi jeden $\mathrm{z}$ kluczowych mechanizmów obronnych człowieka. Oznacza ono zafałszowywanie obrazu rzeczywistości poprzez nieprzyjmowanie do świadomości realnych faktów, które pozwala odrzucić negatywne myśli i odczucia. Przykładem zaprzeczenia jest osoba uzależniona od alkoholu, która twierdzi, że pije dla przyjemności i w każdej chwili może przestać (Kobierzycki, 2001).
} 
lub kogoś - początkowo była to przyroda, zwierzęta czy - ogólnie ujmując - to, co nieznane. Ewolucja przystosowała nas do reagowania na zagrożenia, które są obserwowalne, ale i takie, których skutki są łatwe do wychwycenia (Szpunar, 2018). Zmiany klimatu są na tyle złożone i wielowymiarowe, że jeszcze nie do końca wypracowaliśmy mechanizmy radzenia sobie z nimi, jak i reagowania na nie (Vugt, Giskevicius, Schultz, 2014). Ponadto, często postrzegamy je jako amorficzne, nieco wydumane, a w związku z tym przesadzone (Gifford i in., 2009). Wśród denialistów można spotkać osoby, które przyjmują do świadomości destrukcyjny wpływ człowieka na otaczające go środowisko przyrodnicze, lecz owa świadomość nie przekłada się w żaden sposób na realne działania proekologiczne (Dunlap, 2013).

Badania naukowe wskazują na istnienie dość prężnego i wpływowego ruchu negacjonistycznego, propagującego poglądy zaprzeczające faktom naukowym związanym ze zmianami klimatycznymi. Longitudinalne badania prowadzone w latach 1998-2013 na próbie 16000 publikacji wyraźnie wskazują (Boussalis, Coan, 2016), iż głównym źródłem dezinformacji $\mathrm{w}$ obszarze zmian klimatycznych są konserwatywne think-tanki, które do manipulowania opinią publiczną wykorzystują głównie media społecznościowe oraz blogosferę (Jacques, Dunlap, Freeman, 2008). Badania CBOS-u (Feliksiak, 2016), prowadzone w naszym kraju w 2016 roku, dobitnie wskazują, iż choć wzrasta odsetek osób uznających, że zmiany klimatu są efektem działalności człowieka, to jednocześnie istnieje spory odsetek tych, którzy uważają, iż zmiany klimatu w równym stopniu generuje człowiek, co stanowią one efekt ,naturalny”.

Wielowymiarowość i złożoność kategorii antropocenu stać się może szansą na to, by na nowo, na poważnie i autentycznie zająć się problemami ekologicznymi współczesnego świata. Coraz dobitniej zauważamy, że procesy degeneracji przyrody są niejednokrotnie nieodwracalne i nawet szeroko podejmowane działania zaradcze, nie są w stanie zatrzymać postępujących strat (Kolbert, 2014; Leakey, Lewin, 1999; Baronsky i in., 2011). Po wtóre, badacze zwracają uwagę, iż granica pomiędzy tym, co naturalne, a tym, co wytworzone, zaczyna się zacierać, a więc sama kategoria natury ulega znaczącej redefinicji. Właściwie należy skonstatować, iż kategoria suwerennej natury dzisiaj nie ma racji bytu, tak dalece człowiek ingeruje w jej procesy (por. Pociask-Karteczka 2010). Geoekolodzy zwracają uwagę, iż mamy do czynienia z procesem, który można określić mianem antropopresji. Oznacza ona intensywny, niejednokrotnie dewastujący wpływ człowieka na naturę (Balon, Maciejowski, 2012).

W ostatnich latach obserwować możemy coraz dobitniejszy zwrot ku dźwiękosferze. Cieszące się popularnością soundscape studies, analizują dźwięk jako istotny zasób środowiska, zarzewie znaczeń i doświadczeń estetycznych. Pozostają one komplementarne wobec interdyscyplinarnych badań hałasu, które to traktują dźwięki jako formę zanieczyszczenia środowiska, dysfunkcjonalną wobec człowieka, ale i całego otoczenia ekologicznego (Pawlas, 2015; Leśniowska-Matusiak, Wnuk, 2014; Losiak, 2017). W polskich badaniach nad dźwiękiem, badacze zwykle posługują się takimi kategoriami, jak: audiosfera, fonosfera, sonosfera, słuchokrąg, dźwiękosfera, pejzaż dźwiękowy, krajobraz akustyczny, przestrzeń foniczna, przestrzeń dźwiękowa, klimat akustyczny czy warstwa dźwiękowa krajobrazu (Bernat, 2013, s. 243). 


\section{Pozytywny wpływ krajobrazu na dobrostan a kategoria pejzażu dźwiękowego}

Środowisko, w którym przychodzi nam funkcjonować, w sposób istotny wpływa na wiele procesów społecznych (Bańka 2002). Krajobrazy niosą ze sobą rozliczne wartości symboliczne, emocjonalne, estetyczne, informacyjne czy ekonomiczne (Myga-Piątek, 2012). Wartości estetyczne krajobrazu stanowią istotną składową subiektywnie odczuwanej jakości życia (por. Wojciechowski, 1986). Uznaje się, iż pozytywne odczucia ${ }^{9}$, których dostarcza kontakt z danym krajobrazem, wpływają na doświadczanie radości życia, a także stymulują do działania i intensyfikują działania o charakterze twórczym. Badania prowadzone w obszarze wpływu krajobrazu na dobrostan człowieka wskazują, iż harmonijne pejzaże ${ }^{10}$ pełnią funkcje terapeutyczne (Kopczyński, Skoczylas 2008; Bernat, 2017). Badacz tego fenomenu, Wilbert Gesler (2005) ukuł pojęcie „krajobrazu terapeutycznego” rozumiejąc go jako miejsce, w którym środowisko fizyczne, zabudowa, warunki społeczne, sprzyjają procesowi zdrowienia. W dyskursie naukowym pojawia się także pojęcie „komfortu krajobrazowego", oznaczającego wskaźnik społeczno-psychologicznej, ale także biologicznej jakości życia warunkowanej funkcjonowaniem w określonej przestrzeni krajobrazowej (por. Biernat, 2017). Obcowanie z harmonijnym krajobrazem przyczynia się w sposób istotny do regeneracji, poprawy samopoczucia i redukcji poziomu stresu, ale także sprzyja aktywności społecznej i, co oczywiste, wzmacnia przywiązanie do danego miejsca (Chwalibóg, Wolski, 2015). Obserwacje te znajdują swoje potwierdzenie w teorii biofilii (Wilson, 1984; Trojanowska, 2017), która oznacza naturalny, wrodzony mechanizm łagodzenia napięcia emocjonalnego, odprężenia i zmniejszenia napięcia mięśniowego w wyniku kontaktu z naturą. Ewolucyjnie jesteśmy przystosowani do bliskiego kontaktu z naturą, nie zaś, do obcowania $\mathrm{z}$ intensywnie zindustrializowanymi przestrzeniami, które wywołują $\mathrm{w}$ nas napięcie, stres i niedookreślone pobudzenie.

Kontakt z naturą indukuje rozliczne, bardzo pozytywne zmiany w mózgu, obniża ciśnienie krwi, zmniejsza napięcie mięśniowe (Thompson, 2011; Rose, 2012; Doughty, 2013). Co nie mniej istotne, przyczynia się do poprawy stanu psychicznego osób, a jego szczególnie pozytywny wpływ zaobserwowano u osób cierpiących na depresję (Wolf, Flora, 2010). Proces leczenia i rehabilitacji, szczególnie uzdrowiskowej, wspomagany jest „sylwoterapią" (Karjalainen, Sarjala, Ratitio, 2010), czyli leczniczym oddziaływaniem lasu. Okazuje się, że już piętnastominutowy spacer po lesie wywołuje bardzo korzystne zmiany w obrębie układu nerwowego, jak i hormonalnego (Park i in., 2010). Polskie badaczki tego fenomenu postulują, by mówić o terenoterapii (Ponikowska, Marciniak, 1988), rozumianej jako dobroczynny wpływ aktywności fizycznej, połączonej z kontaktem z atrakcyjnym wizualnie krajobrazem. Z kolei w opiece geriatrycznej, ale także w obszarze licznych zaburzeń psychicznych, eksperymentuje się horitoterapią, która wykorzystuje pracę w ogrodzie (Dorn, Relf, 1995).

\footnotetext{
${ }^{9} \mathrm{Z}$ drugiej strony, krajobrazy, które odbieramy jako brzydkie, chaotyczne, zaśmiecone czy zdewastowane, mogą przyczyniać się do apatii, a także zachowań agresywnych (Bernat, Kałamucka, 2008).

${ }^{10}$ Harmonia krajobrazu stanowi estetyczny wymiar jego pojmowania, przejawiający się w ocenie jego doskonałości, zrównoważenia. Harmonię krajobrazu określa się także jako współwystępowanie określonych jego elementów, które przez obserwatora są odbierane jako właściwe, zharmonizowane, adekwatne (Wojciechowski, 1986).
} 
Kategoria pejzażu dźwiękowego w dyskursie naukowym pojawiła się dzięki kanadyjskiemu kompozytorowi Raymondowi Murrayowi Schaferowi (1977) ${ }^{11}$. Schafer terminem tym, chciał zwrócić uwagę na przemiany zachodzące w krajobrazie dźwiękowym, zmieniające się funkcje dźwięku, a także zmiany w obrębie samych dźwięków docierających do ludzkiego ucha na przestrzeni wieków. Trzeba przy tym wyraźnie zaznaczyć, iż Schafer właściwie nie wyjaśnił szczegółowo znaczenia tego terminu, choć posługiwał się nim wielokrotnie, a inni badacze chętnie zaaplikowali ten nośny termin do badań środowiska dźwiękowego. Kompozytor pojęcie to ujmuje dość lapidarnie, jako konkretne środowisko dźwiękowe, które może zostać poddane badaniom, przy czym zaznacza, że można je odnosić zarówno do środowisk rzeczywistych, jak i sztucznych, abstrakcyjnych, jakimi są kompozycje, nagrania czy audycje (Kapelański, 1999).

Sebastian Bernat zauważa, iż „Dźwięk jest dynamiczny jako najbardziej zdarzeniowy spośród postrzeganych fenomenów, nie można go zatrzymać, rozpatrywać w oderwaniu od źródła i siły, która go wytworzyła" (2015, s. 47). Na pejzaż dźwiękowy Schafer (1982) patrzył jak na makrokosmiczną kompozycję wymagającą słuchania równie uważnego, jak symfonia Wolfganga Amadeusza Mozarta. Schafer w swoich pracach ukuł pojęcie ekologii akustycznej, którą pojmował jako subtelną równowagę ,między organizmami żywymi, ludźmi i ich środowiskiem akustycznym. Gdy dźwięk otoczenia osiąga takie proporcje, że ludzkie głosy są zamaskowane lub przytłoczone, to znaczy, że stworzyliśmy środowisko nieludzkie" (1982, s. 312). Epoka antropocenu zdominowana przez ludzką działalność i dźwięki antropogeniczne staje się środowiskiem nieprzyjaznym dla wielu organizmów, w tym także dla samego człowieka. Jak trafnie konstatuje Maria Gołaszewska, „w sferze akustycznej od odgłosów przechodzimy do skierowanych do kogoś głosów, które otwierają przed nami nowy wymiar świata: świata, który czegoś od nas żąda, przyzywa nas, a także świata, który nas o czymś informuje" (1997, s. 78). Filozofka wyróżniła audiosferę potoczną, która obejmuje dźwięki najbliższego, prywatnego otoczenia, audiosferę zorganizowaną, którą tworzą zróżnicowane odgłosy otoczenia, głównie przyrodniczego oraz audiosferę wyspecjalizowaną, którą tworzą dźwięki unikalne dla danego środowiska.

Schafer podaje bardzo prostą, wydaje się banalną receptę na poprawę krajobrazu dźwiękowego (1995, s. 6):

Musimy się nauczyć słuchania. Wygląda to na utraconą zdolność. Musimy wyczulić nasze ucho na wspaniały świat dźwięków wokół nas. Gdy rozwiniemy w sobie pewną krytyczną przenikliwość, możemy przejść do większych przedsięwzięć o znaczeniu społecznym, tak że nasze doświadczenia mogą wpłynąć na innych. Ostatecznym celem byłoby umożliwienie podejmowania świadomych decyzji dotyczących naszego dźwiękowego otoczenia.

Schafer dodaje, iż w tym przypadku nie mają znaczenia żadne regulacje prawne, chodzi bowiem raczej o edukowanie, rozwijanie świadomości indywidualnej i zbiorowej. Za kluczową w tym obszarze uznawał praktycznie nieobecną w programach szkolnych naukę

${ }^{11}$ Choć to nazwisko Schafera (1977) jest kojarzone z pejzażem dźwiękowym, trzeba zaznaczyć, iż prawdopodobnie jako pierwszy użył tego terminu Alvin Lucier, odnosząc go do swoich muzycznych kompozycji (Kapelański, 2005). 
świadomego słuchania ${ }^{12}$. Kompozytor postulował o pogłębione, czyli uważne i dociekliwe słuchanie, które pozwala różnicować z otoczenia najbardziej subtelne dźwięki.

Istotnym aspektem edukacji dźwiękowej jest eliminowanie nawykowego i bezrefleksyjnego nadużywania dźwięków, na przykład automatycznego włączania telewizora czy radia. Te nieuświadomione praktyki sprawiają, że słuchanie muzyki przez słuchawki staje się dość częstym wzorcem zachowania w przestrzeni publicznej, szczególnie w środkach komunikacji miejskiej. Jak słusznie konstatuje Robert Losiak, „człowiek odcięty od prawdziwej i rzeczywistej sytuacji dźwiękowej otoczenia staje się jeszcze mniej wrażliwy na środowisko akustyczne i skłonny do dbałości o jego stan" (2017, s. 120). Trudno bowiem dbać o to, co jest dla nas niezauważalne, a przez to oczywiste i nie wymagające specjalnego traktowania.

Muzykolożka Anna Maria Harley w jednym ze swoich artykułów, który można potraktować jako swoisty manifest, pisze o konieczności mówienia o ekologii dźwiękowej (1995, s. 6):

Czas na zmianę: czas na ekologię dźwiękową, czas na otwarcie okien i uszu na dźwięki otaczającego świata, dźwięki tym cenniejsze, że zagrożone zniszczeniem przez wszechobecny ludzki hałas. Zagrożeniem jest zniszczenie ciszy. Już nie ma chyba na naszej planecie miejsc, z których nie byłoby słychać silników samolotów: niebo z siedliska bogów zmienia się w ,rynsztok dźwiękowy”.

Jak bardzo Harley miała rację, potwierdzają badania nad strefami ciszy, których właściwie już nie mamy, a o których piszę w dalszej części tego tekstu. Trudno nie przyznać racji Danucie Gwizdalance, która wskazuje, iż nie potrafimy już obcować z ciszą, a naszą przestrzeń społeczną zdominował hałas i wszędobylska muzyka (1987a, s. 23). Za hałas należy uznać każde niepożądane zjawisko akustyczne, zatem i muzyka, kiedy nie chcemy lub nie mamy ochoty jej słuchać, może być za taki uznana (Pawlas, 2015, s. 51).

$\mathrm{Na}$ nadmiarowość muzyki w miejscach publicznych i prywatnych zwracał uwagę Witold Lutosławski, który uznawał tego typu praktyki za „niedopuszczalne pogwałcenie wolności osobistej i prawa każdego człowieka do ciszy" (Gwizdalanka, 1995, s. 60). Kompozytor był przekonany, że otaczanie się pseudomuzyką prowadzi do tępienia naszej wrażliwości, a w konsekwencji może wywoływać stan, który określa mianem „dźwiękowstrętu” ${ }^{13}$. W tym kontekście zaczyna się coraz wyraźniej mówić o agresji fonicznej, która rozumiana jest jako świadome zanieczyszczenie lub umyślne epatowanie dźwiękami (Kasprzak, 2014).

Wydaje się, że tak bardzo przyzwyczailiśmy się do nadmiarowości muzaków w przestrzeni publicznej $^{14}$, że traktujemy je jako naturalny element społecznego krajobrazu, nie radząc sobie z ciszą, która dla wielu staje się nieznośną pustką. Gwizdalanka w swojej diagnozie posuwa się jeszcze dalej uważając, że akustyczne zanieczyszczenie środowiska „zbliża się do granicy ludzkiej wytrzymałości, a zdegradowana do roli narkotyku muzyka przestaje pełnić swą

\footnotetext{
${ }^{12}$ Co ciekawe, Schafer postulował o świadomość dźwięków, które towarzyszą wielu naszym codziennym czynnościom, co wpisuje się w postulaty uważności, nie tylko w tej sferze.

${ }^{13}$ Lutosławski 2013 Manifest. O równowagę dźwięków i ciszy, https://www.muzykajest.pl/lutoslawski-2013manifest-o-rownowage-dzwiekow-i-ciszy/

${ }^{14} \mathrm{O}$ powszechności muzyki w przestrzeni publicznej, szczególnie w jej wymiarze społeczno-ekonomicznym interesująco pisze Makomaska (2012).
} 
tradycyjną kulturotwórczą rolę" (1987, s.10). Pustkę milczenia próbujemy zapełnić przez dowolną, przygodną gadaninę (Heidegger, 1977), którą równie równie dobrze mogą stać się quasi komunikacyjne small talki, co odcinająca nas od kontaktu z zewnętrznym światem muzyka. Niezwykle wymownie o nadmiarowości, ględzeniu, tokowaniu, ale i bezsensie dźwięków, które bezrefleksyjnie wydajemy z siebie, pisał Ryszard Kapuściński (1997, s. 42-43):

Słowa staniały. Rozmnożyły się, a straciły na wartości. Są wszędzie. Jest ich za dużo. Mrowią się, kłębią, dręczą jak chmary natarczywych much. Ogłuszają. Tęsknimy więc za ciszą. Za milczeniem. Za wędrówką przez pola. Przez łąki. Przez las, który szumi, ale nie ględzi, nie plecie, nie tokuje.

\section{Rola i znaczenie dźwięków w przestrzeni społecznej}

Grupa badaczy zajmująca się soundscape ecology ${ }^{15}$, wyróżniła w krajobrazie dźwiękowym trzy kluczowe rodzaje dźwięków (Pijanowski i inni, 2011). Pierwszymi z nich są biofony, będące dźwiękami przyrody ożywionej (głównie odgłosy zwierząt), geofony, które stanowią dźwięki przyrody nieożywionej (dźwięki wiatru, wody, piorunów etc.) oraz antrofony, czyli dźwięki wytwarzane przez człowieka. Jak wykażę w dalszej części artykułu, to właśnie dźwięki wydawane przez naturę - biofony i geofony, są przez nas odbierane jako najbardziej kojące, uspakajające, a w konsekwencji najbardziej pożądane. Antrofony okazują się męczące, nadmiarowe, a nawet drażniące dla człowieka poszukującego spokoju i wyciszenia.

Dźwięk z reguły wskazuje na aktywność ludzkich istot, cisza bywa zagrożeniem dla ludzkiej egzystencji, jest interpretowana jako złowroga, niepożądana i zagrażająca (Bernat, 2013, s. 242-243). Cisza powinna być dla nas bardzo ważną wartością i istotnym sygnałem. Wybitny reportażysta Ryszard Kapuściński konstatował (1990, s. 195):

Cisza - Ludzie, którzy piszą historię, zbyt dużo uwagi poświęcają tzw. głośnym momentom, a za mało badają okresy ciszy. Jest to brak intuicji tak niezawodnej u każdej matki, kiedy usłyszy, że w pokoju jej dziecka raptem zrobiło się cicho. Matka wie, że ta cisza oznacza coś niedobrego. Że jest to cisza, za którą coś się kryje. Biegnie interweniować, ponieważ czuje, że zło wisi w powietrzu.

Nie sposób pominąć tego, jak bogata komunikacyjnie może być cisza, jak brak dźwięków aktywować w nas może strach, poczucie zagrożenia i nadchodzące niebezpieczeństwo. Zapełniona hałasem i nadmiarem bodźców przestrzeń pozbawia nas czujności i uważności dwóch niezmiernie istotnych wymiarów naszego funkcjonowania.

Pomiędzy człowiekiem, a jakimś miejscem może zaistnieć szczególny związek przynależności lub posiadania (Pawłowska, 2002). Jak zauważa Bernat (2013), w doświadczaniu krajobrazu przeważa percepcja wzrokowa, jednakże jego doświadczanie jest multisensoryczne. Trzeba przy tym zauważyć, że duże natężenie hałasu powodować może, że zmysłem dominującym zaczyna być słuch, a intensywność nieprzyjemnego zapachu może

\footnotetext{
15 Soundscape ecology podejmuje problematykę z zakresu ekologii akustycznej, bioakustyki, ekologii przestrzeni i psychoakustyki.
} 
sprawiać, że odbiór krajobrazu odbywa się „węchowo” (Carles, Barrio, de Lucio, 1999). Krajobraz dźwiękowy traktować należy jako nośnik pewnych treści, skojarzeń i symboliki, a w niemal każdym z nich mamy do czynienia z dźwiękami, które są szczególnie ważne dla danej społeczności (Bernat, 2011, s. 202). W literaturze mówi się nawet o społecznościach akustycznych (acoustic community), dla których informacja akustyczna odgrywa ważną rolę (Kapelański, 1999). Dziewiętnastowieczne relacje z podróży Aleksandra von Humbolta obfitują w opisy środowiska dźwiękowego. Kluczową rolę przypisuje on ciszy, która uwrażliwia na dźwięki i stanowi źródło estetycznych doświadczeń (Humbolt, 1959). Sama podróż może odbywać się właśnie z ukierunkowaniem na dźwiękosferę, w poszukiwaniu miejsc unikalnych, nietuzinkowych, co może stanowić wypadkową poszukiwania nowych, kontemplacyjnych doświadczeń. Jak zauważa Wojciech Mann: „dźwiękowa podróż kryje w sobie jakąś magiczną, nieuchwytną tajemnicę" (Ucho na świat ..., 2010). Zdaniem Josepha Amato (2002), badanie krajobrazu dźwiękowego powinno stać się jednym z kluczowych obszarów badania społeczności lokalnych. Sebastian Bernat (2013) wskazuje, że choć krajobraz dźwiękowy jako wartość niematerialna jest niemierzalny, to możliwe jest określanie wrażliwości tego środowiska na hałas. W obszarach cennych przyrodniczo każda forma hałasu antropogenicznego, traktowana jest jako zakłócająca i utrudniająca percepcję natury.

Należy przy tym wskazać, że choć hałas traktujemy jako przeciwieństwo ciszy, w ujęciu Schafera cisza nie oznacza braku dźwięków, ale środowisko, które jest nieprzepełnione dźwiękowo, właściwe dla obszarów, które określa mianem hi-fi. Pejzaż dźwiękowy typu $h i-f i$ jest właściwy dla obszarów wiejskich i terenów niezurbanizowanych (Losiak, 2012). Dźwięki w tych obszarach są dobrze słyszalne i nie nakładają się na siebie, nie maskują wzajemnie, współgrając $\mathrm{z}$ miejscem $\mathrm{w}$ którym funkcjonują. W przypadku obszarów lo-fi dźwięki nakładają się na siebie, maskują wzajemnie, nie są wyraziste, a cały krajobraz dźwiękowy jest zuniformizowany (Bernat, 2013, s. 244).

Robert Losiak popularności pojęcia pejzażu dźwiękowego upatruje w inspirowaniu, pobudzaniu „muzyczno-dźwiękowej wyobraźni, skierowania uwagi bardziej w stronę estetycznego odczuwania niż poznawczego rozpoznawania otoczenia dźwiękowego audiosfery" (2015, s. 45). Losiak wskazuje na ważną dystynkcję - o ile środowisko akustyczne można odczytywać jako istniejące obiektywnie, poza naszą świadomością i oceną, o tyle pejzaż dźwiękowy, o którym pisze Schafer jest tym, co jest postrzegane, odczuwane i waloryzowane przez człowieka. Badacz w koncepcji pejzażu dźwiękowego upatruje impulsu wyzwalającego naszą troskę wobec środowiska dźwiękowego (Losiak, 2005, s. 82-90). Jest to interpretacja zgodna z tym, jak na krajobraz patrzył Stanisław Pietraszko (1992), który uznawał, iż doświadczenie krajobrazu polega na nadawaniu znaczeń i wartości jakiemuś fragmentowi środowiska. Inaczej ujmując, nie ma obiektywnego krajobrazu, istnieją jedynie krajobrazy subiektywne, które niosą ze sobą różne znaczenia, zależne od obserwujących je aktorów. Kulturoznawca zwracał uwagę, iż o krajobrazie jako takim, można było mówić dopiero wtedy, gdy przestał on być dla człowieka jedynie źródłem korzyści, a stał się wartością samą w sobie. Dopiero w sytuacji zawieszenia utylitarnego znaczenia przestrzeni, zaczynamy dostrzegać jej wymiar estetyczny. 


\section{Hałas jako wyzwanie XXI wieku}

Hałas stanowi jedno z najpoważniejszych wyzwań XXI wieku, a pomimo tego jest on ciągle niedocenianym zagrożeniem, które dodatkowo niemal stale rośnie (EEA Report, 2014; Pawlas, 2015). Nie jest problemem właściwym wyłącznie dla czasów współczesnych, według źródeł w czasach starożytnych hałas wytwarzany przez urządzenia techniczne stanowił 5\%, ogólnej puli akustycznej, zaś dźwięki generowane przez naturę niemal 70\%. Współcześnie relacje te uległy odwróceniu (de Hollander, Kempen, Stasstsen, 2004). Wysycone hałasem przestrzenie, na przykład o charakterze przemysłowym, są niepożądane, wpływając na obniżenie cen nieruchomości w takich obszarach (Senetra, Szczepańska, WasilewiczPszczółkowska, 2014).

Według danych raportu Europejskiej Agencji Środowiska (EEA Report, 2014), na hałas drogowy o poziomie $55 \mathrm{~dB}$ narażonych było około 90 milionów mieszkańców miast i około 28 milionów osób spoza obszarów miejskich. Ponadto aż 10 milionów osób narażonych jest na hałas kolejowy, około 3 milinów na hałas lotniczy i około 1 miliona na hałas przemysłowy. Ten sam raport zwraca uwagę, iż co drugi mieszkaniec naszego kraju narażony jest na hałas powyżej $55 \mathrm{~dB}$. Realnie liczba osób narażonych na hałas jest znacznie większa, gdyż z reguły bada się wyłącznie źródła hałasu generowane przez transport. Hałas jest nie tylko pewną uciążliwością, ale taką formą zanieczyszczenia środowiska, która rodzi realne zagrożenie dla zdrowia (Pawlas, 2015).

Sam dźwięk jest zwykle definiowany jako „każde rozpoznawalne przez człowieka wrażenie słuchowe", które kształtuje nasze doświadczenia (Bernat, 2015, s. 46) ${ }^{16}$. Za dźwięk uznaje się słyszalne przez ludzi drgania o częstotliwościach od $16 \mathrm{~Hz}$ do $20 \mathrm{kHz}$, choć pamiętać należy, iż dźwiękiem są także drgania niesłyszalne przez ludzi, a więc ultradźwięki (drgania o częstotliwości powyżej $20 \mathrm{kHz}$ ) i infradźwięki (drgania o częstotliwościach poniżej 16 $\mathrm{Hz})^{17}$. W sytuacji, gdy poziom hałasu jest zbyt duży, może tworzyć się ciśnienie powodujące ból wewnątrz ucha, uszkodzenie słuchu, a nawet jego utratę. Uznaje się, iż granica bólu ${ }^{18}$ pojawia się przy wartości $130 \mathrm{~dB}$ (Leśniowska-Matusiak, Wnuk, 2014). Dodatkowo wskazuje się, że mała uciążliwość hałasu dotyczy poziomu poniżej $52 \mathrm{~dB}$, średnia 52-62 dB, duża 63 $70 \mathrm{~dB}$, zaś bardzo duża dotyczy hałasu powyżej $70 \mathrm{~dB}$. Hałasy poniżej $35 \mathrm{~dB}$ dla zdrowia są nieszkodliwe, mogą jednak przeszkadzać w skupieniu się i wywoływać irytację, 35-70 dB poważeni utrudniają zrozumienie werbalizowanych słów, zasypianie i wypoczynek, 70-85 dB stają się szkodliwe dla zdrowia, zmniejszają wydajność pracy, mogą powodować uszkodzenia słuchu. Najbardziej zagrażający dla zdrowia jest poziom 85-130 dB, generuje liczne schorzenia i dysfunkcje, zaś hałas powyżej $130 \mathrm{~dB}$ pobudza drgania organów wewnętrznych

\footnotetext{
${ }^{16}$ Należy nadmienić, iż część muzykologów nie zgadza się z tym stwierdzeniem. Na przykład, Maciej Gołąb (2011) nie zgadza się z tym, iż dźwiękiem jest wszystko to, co słyszymy, uznając, że dźwięk jest daną słuchowo jakością.

${ }^{17}$ Powinniśmy mieć na uwadze, iż hałas o częstotliwościach, które nie są słyszalne dla człowieka wywiera negatywny wpływ na organizmy żywe analogicznie, jak hałas słyszalny.

${ }^{18}$ Jednostką dokuczliwości hałasu jest noys. 1 noys oznacza dokuczliwość (dla przeciętnej wrażliwości na hałas) dźwięku o częstotliwościach w zakresie 910-1090 Hz i natężeniu 40 dB (Leśniowska-Matusiak, Wnuk, 2014).
} 
organizmu i powoduje trwałe uszkodzenie słuchu (Leśniowska-Matusiak, Wnuk, 2014). Przykładowe poziomy różnych źródeł dźwięku przedstawiono w tabeli.

\begin{tabular}{|c|c|}
\hline Wartość [dB] & Rodzaj dżwię ku \\
\hline 160 iwięcej & HAKASŚMIERTELNY \\
\hline $155-160$ & HALAS POWODUJĄCY WSTRZĄS MÖZGU \\
\hline $150-155$ & HAKAS POWODUJĄCY TRWAKE USZKODZENIE SKUCHU \\
\hline $145-150$ & Samolot odrzutowy podczas startu zodległośa $10 \mathrm{~m}$ \\
\hline $140-145$ & Syrena a lar mowa zodlegiości 1 m \\
\hline $135-140$ & Silnik samolotuśmigłowego \\
\hline $130-135$ & Prasa hydrauliczna zodlegiości $0,5 \mathrm{~m}$ \\
\hline $125-130$ & GRANICA BÓLU \\
\hline $120-125$ & Karabin maszynowy z odległości $0,5 \mathrm{~m}$ \\
\hline $115-120$ & Młot pneumatyczny zodległośa $5 \mathrm{~m}$ \\
\hline $110-115$ & Dyskoteka \\
\hline $105-110$ & Metroz odległości $3 \mathrm{~m}$ \\
\hline $100-105$ & Koncert muzyki rozrywkowej \\
\hline $95-100$ & Klakson samochodowy zodległości 5 m \\
\hline $90-95$ & Swider pneumatyczny zodległości 2 m \\
\hline $85-90$ & Wnętrze autobusu \\
\hline $80-85$ & Krzykz odległości $1 \mathrm{~m}$ \\
\hline $75-80$ & Dzwonek telefonuz odległości $2 \mathrm{~m}$ \\
\hline $70-75$ & Silnik samochodu osobowego $z$ odległości $6 \mathrm{~m}$ \\
\hline $65-70$ & Domowa maszyna do szycia \\
\hline $60-65$ & Głośna rozmowa z odległosci $2 \mathrm{~m}$ \\
\hline $55-60$ & Dzwon kościelny z odległości $400 \mathrm{~m}$ \\
\hline $50-55$ & Male pomieszczenie biurowe, maly sklep \\
\hline $45-50$ & Spokojna rozmowa \\
\hline $40-45$ & Cicha ulica \\
\hline $35-40$ & Darcie papieruz odległości $1 \mathrm{~m}$ \\
\hline $30-35$ & Szpital, kościół, czytelnia \\
\hline $25-30$ & Bardzo ciche pomieszzzenie, tykanie zegara zodleg $10 s \dot{d} 1 \mathrm{~m}$ \\
\hline $20-25$ & Studio radiowe lub filmowe \\
\hline $15-20$ & Szept przeciętny z odległości $2 \mathrm{~m}$ \\
\hline $10-15$ & Szept cichy $z$ odległości $2 \mathrm{~m}$ \\
\hline $5-10$ & Oddech zodległości $0,5 \mathrm{~m}$ \\
\hline $0-5$ & Szmer liści w bezwietrzny dzień z odległośa $3 \mathrm{~m}$ \\
\hline 0 & ṠREDNI PRÓG SKYSZENIAZDROWEGO UCHA \\
\hline
\end{tabular}

Tabela. Poziomy różnych źródeł dźwięku wyrażone w decybelach. Opracowanie własne na podstawie (Leśniowska-Matusiak, Wnuk, 2014, s. 40). 
Uznaje się, że wartość progowa dla hałasu lotniczego, drogowego i kolejowego wynosi $42 \mathrm{~dB}$ (Miedema, Oudshoorn, 2001). WHO podaje, że na całym świecie około 1.3 miliardów ludzi narażonych jest na taki poziom hałasu, że zagrożeni są ubytkiem słuchu. Ponadto, w przypadku nadmiernej ekspozycji na hałas, pojawiają się problemy ze strony układu krążenia, zaburzenia snu, upośledzenia zdolności poznawczych oraz szumy uszne (Pawlas, 2015, s. 50). Szerokiego przeglądu negatywnych skutków zdrowotnych ekspozycji na hałas dokonuje Krystyna Pawlas (2015). Badania, na które się powołuje, mówią o ryzyku nadciśnienia tętniczego, gdy poziom hałasu w środowisku zaczyna przekraczać $65 \mathrm{~dB}$. Ponadto wykazano wzrost ryzyka zawałów serca i udarów mózgu, w grupach, które zawodowo są wystawione na hałas. Aż 80-90\% zaburzeń snu ma swoje źródło w intruzji spowodowanej hałasem, a zmiany w jakości snu są już odnotowywane przy poziomie $30 \mathrm{~dB}$. Jeśli hałas przekracza $55 \mathrm{~dB}$ sen staje się zupełnie nieefektywny, nie zapewniając regeneracji (Pawlas, 2015).

Jak pokazują badania, głównymi determinantami szkodliwości hałasu jest jego natężenie, zmienność w czasie oraz charakter (Kryter, 1970). Jak podaje Krystyna Pawlas (2015), reakcje na hałas uwarunkowane są także zmianami dobowymi - wieczorem i nocą jesteśmy na hałas wyczuleni bardziej, podczas, gdy w dzień tolerancja dla hałasu jest większa. Ponadto, tolerancja na hałas zwiększa się wraz z wiekiem i już około 60 roku życia jest znacznie większa. Choć o tym zapominamy, poważne ryzyko niesie ze sobą systematyczne, głośne słuchanie muzyki, które może prowadzić nawet do ubytków słuchu.

Badania CBOS (Wciórka, 2009) wskazują, że większość respondentów (71\%) odczuwa hałas jako uciążliwy i męczący. Hałas ankietowanym dokucza głównie na ulicach (56\%), w miejscu pracy $(46 \%)$, w środkach komunikacji $(33 \%)$, w supermarketach $(25 \%)$, w mieszkaniach (21\%) oraz w miejscach wypoczynku (12\%). Hałas w pracy to głównie działanie maszyn i sprzętu biurowego (37\%), w domu zaś głównym źródłem hałasu jest hałas uliczny (33\%) oraz osiedlowy (16\%), a także panujący wewnątrz samego mieszkania (14\%) lub pochodzący od sąsiadów (11\%). Co dziesiąty ankietowany respondent wskazuje na kłopoty ze zdrowiem i samopoczuciem, które hałas wywołuje. Przede wszystkim jest to nerwowość, rozdrażnienie i nadpobudliwość $(75 \%)$, przemęczenie (70\%), bóle głowy, migreny $(67 \%)$ oraz przytępienie słuchu (52\%). Polacy na różne sposoby radzą sobie z hałasem. Głównie wyciszają mieszkania i inne pomieszczenia (18\%), unikają hałaśliwych miejsc (14\%), próbują go ignorować, przyzwyczajać się $(6 \%)$, sporadycznie podejmują próby interwencji u hałasujących lub u władz (3\%). Aż co czwarty ankietowany nie podejmuje żadnej aktywności w tym zakresie.

Badania poświęcone pejzażowi dźwiękowemu Wrocławia (Losiak, Tańczuk, 2014) jednoznacznie wskazały, iż świadomość środowiska dźwiękowego jest wśród badanych bardzo niska. Jednocześnie należy zauważyć, iż w trakcie wywiadów, problematyka ta, wzbudzała dość duże zainteresowanie i zaciekawienie tematem, a sami badani przyznawali, iż choć tematyka ta, nie była do tej pory przedmiotem ich refleksji, jest warta analizy. Zaskoczeni problematyką rozmówcy z pasją odpowiadali o swoich doświadczeniach, związanych $\mathrm{z}$ audiosferą miasta, wykazując emocjonalny i zaangażowany stosunek do dźwięków ze swojego otoczenia. Dodać należy, iż sam fakt prowadzenia badań i uświadomienia istotności tej problematyki niósł w sobie spory walor edukacyjny. 


\section{Przestrzenie przyjazne dźwiękowo}

Bernat, prowadząc badania nad miejscami przyjaznymi dźwiękowo $(2011)^{19}$, zwrócił uwagę, iż miejsca te, to głównie krajobrazy dźwiękowe związane z lasem, parkami i ogrodami botanicznymi, morzem oraz obszarami nadmorskimi, a także łąkami. Głównymi czynnikami, decydującymi o przyjazności dźwiękowej danego miejsca, jest zdaniem ankietowanych, cisza, spokój, harmonia, obecność przyrody i brak odgłosów miasta. Piękno dźwięków wytwarzanych przez naturę oddaje wnikliwy Kapuściński (1997, s. 168):

Gdy się idzie przez pola z Nałęczowa do Wąwolnicy, słychać, jak ziemia śpiewa. I nie jest tak, że gdzieś rozlegnie się jakiś samotny głos, a gdzieś później, w innym miejscu inny. Śpiew słychać zewsząd - z pól, ze wzgórz, z mijanych zagajników. Ziemia śpiewa głosami ptaków, ale ptaków nie widać, bo świeci słońce, jest upał i kryją się one w cieniu miedz, moszczą w bruzdach, buszują w wysokich zbożach. Ten śpiew nie milknie ani na sekundę. $Z$ obu stron drogi dobiegają nas świergoty i trele, soprany i alty, nucenia, szczebiotania. Przez cały czas z ziemi unosi się donośna muzyka - wielostrunna, wielogłosowa kantata na ptasi chór i orkiestrę, która uprzyjemnia nam wędrówkę.

Odmalowana przez reportażystę symfonia dźwięków natury wydaje się tak olśniewająca i kojąca, iż nie sposób konkurować z naturą w jej fonicznej doskonałości. Każda próba jej odtworzenia będzie tylko nieudolną kopią doskonałości natury.

Za nieprzyjazne dźwiękowo uznano ulice, centrum miasta, szkoły, supermarkety, galerie handlowe, place budowy, dworce PKP i PKS, autostrady, puby, dyskoteki. Kluczowymi zmiennymi, decydującymi o pejoratywnej ewaluacji tych miejsc była intensywność hałasu komunikacyjnego, głośna muzyka, wrzaski, agresywność dźwięków. Dźwięki te, przez badanych, były odczuwane jako „ostre, wszechogarniające, agresywne, sztuczne. Człowiek czuje się zagubiony, dźwięki drażnią, zakłócają spokój, wywołują frustrację, przerażenie, lęk, strach, niepewność, odwracają uwagę, stwarzają odczucie chaosu” (Bernat, 2011, s. 201).

Oceny pejzażu dźwiękowego najczęściej dokonuje się poprzez dychotomię hałas - cisza, która dominuje także w potocznych ocenach fonosfery (Kasprzak, 2014). Oba wymiary mogą być przez nas postrzegane jako źródło przyjemności, przy niekoniecznym ukierunkowaniu na ciszę $^{20}$ (por. Szpunar, 2017). Dźwięki otoczenia mogą na tyle intensywnie angażować nasze zmysły, że pojawia się próg bólu. John Grossmann i Gordon Hempton (2009), badający strefy ciszy $^{21}$, zwrócili uwagę, iż właściwie nie ma w tej chwili miejsca na ziemi, które byłoby w stu

\footnotetext{
${ }^{19}$ Badanie zostało przeprowadzone w 2010 roku na próbie 124 respondentów w wieku 20-25 lat, studentów UMCS. Choć badanie to nie ma charakteru reprezentatywnego, wnioski z badania stanowią interesującą poznawczo ilustrację postrzegania fonosfery miasta.

${ }^{20}$ Subiektywna wrażliwość na hałas jest determinowana indywidualnymi właściwościami człowieka, a także cechami fizycznymi dźwięku. Ocena hałasu zależy od takich zmiennych, jak: wiek, wrażliwość, stan zdrowia, odporność psychiczna oraz chwilowy nastrój człowieka. Dokuczliwość hałasu może potęgować jego niespodziewane wystąpienie.

${ }^{21}$ Ustawa Prawo do ochrony środowiska wprowadza kategorię „obszarów cichych”. Jest to obszar, na którym nie występują przekroczenia dopuszczalnych poziomów hałasu. Obszar cichy poza aglomeracją nie jest narażony na hałas komunikacyjny, przemysłowy lub rekreacyjno-wypoczynkowy.
} 
procentach wolne od hałasu generowanego przez człowieka. Jeszcze w latach 80 . XX wieku w stanie Waszyngton istniało prawie dwadzieścia miejsc w których interwały ciszy wynosiły do 15 minut. Obecnie w amerykańskich parkach narodowych interwały ciszy, niezakłócone hałasem cywilizacyjnym, wynoszą maksymalnie 5 minut. Do wyjątkowych pod tym względem miejsc badacze zaliczyli Hoh Rain Forest w Olimpic National Park ${ }^{22}$. W miejscu tym, cisza niezmącona hałasem antropogenicznym trwa godzinami, przez co zyskało ono miano One Square Inch of Silence. Grossmann i Hempton wyraźnie wskazują, że cisza staje się zasobem coraz rzadszym, a w związku z tym, powinna być objęta ochroną.

Zwrócić należy uwagę, iż dźwiękosfera coraz częściej jest doceniania i traktowana jako istotny element naszego dobrostanu psychicznego. Powstaje szereg projektów, uwrażliwiających na brzmienie miejsc. Organizacja Sonic Arts Network zrealizowała program edukacyjny „Sonic Postcards” - „Pocztówki dźwiękowe”, w ramach którego uczniowie w wieku 9-14 samodzielnie rejestrowali wybrane przez siebie krajobrazy dźwiękowe, uznano za najbardziej atrakcyjne. Podobne akcje odbyły się w Finlandii i Japonii. W Polsce do bardziej interesujących inicjatyw w tym względzie należą „Dźwięki Małopolski”, „Pocztówki Dźwiękowe z Opactwa Benedyktynów w Tyńcu”, „Tonopolis”, „Dźwiękospacery” czy „Pocztówki z Bytomia” (Bernat, 2013). Do pozytywnych działań w tym obszarze z pewnością zaliczyć należy brytyjski program Campaign to Protect Rural England Tranquility (Bernat, 2011). Pojęcie tranquility jest rozumiane jako piękno, cisza, spokój, równowaga, różnorodność oraz słyszalność dźwięków przyrody, szczególnie kojarzonych z obszarami wiejskimi. W tym ujęciu tranquill areas są rozumiane jako strefy oddalone od cywilizacyjnych intruzji ${ }^{23}$. Sebastian Bernat (2013) wskazuje na ciekawy flandryjski projekt „Dender-Mark Silence Area”, którego celem jest pielęgnowanie ciszy.

Ciekawą inicjatywą są również ,spacery dźwiękowe” (soundwalks). Polegają one na twórczym i uważnym poznawaniu środowiska dźwiękowego podczas naturalnego przemieszczania się. Hildegarda Westerkamp (2015) postulująca o tego typu aktywność zwraca uwagę, iż nasze środowisko dźwiękowe znajduje się w stanie równowagi, jeśli w trakcie przemieszczania się słyszymy własne kroki i nie musimy forsować głosu.

Sebastian Bernat analizując polskie programy ochrony środowiska przed hałasem ${ }^{24}$, zwrócił uwagę, iż działania w tym obszarze, zwykle ograniczają się do obudowywania głównych arterii komunikacyjnych ekranami akustycznymi lub wymiany stolarki okiennej. Właściwie nieobecne są wydzielone strefy ciszy, bądź ograniczenia w ruchu pojazdów (Bernat, 2010). Jednocześnie trzeba wskazać, że samo wyznaczanie stref ciszy bywa przedmiotem wielu

\footnotetext{
22 Parki narodowe Stanów Zjednoczonych przywiązują dużą wagę do aktywnej ochrony ciszy. W tym celu wyznacza się akustyczne strefy ciszy, bada się oczekiwania turystów oraz prowadzi rozliczne akcje edukacyjne. Istotną rolę pełni tutaj program nagrywania krajobrazów dźwiękowych Wild soundscapes in the national park (Bernat, 2007).

${ }^{23} \mathrm{~W}$ Londynie opracowano „Strategię walki z hałasem”: planowanie ma na celu minimalizowanie hałasu, promowanie strefy ciszy oraz zachowanie najcenniejszych, unikalnych krajobrazów dźwiękowych (Bernat, 2011).

${ }^{24}$ Zwrócić należy uwagę, iż analizy Bernata pochodzą z lat 2009-2010 i choć wiele się od tego czasu zmieniło, trudno mówić o jakieś rewolucji w tym zakresie.
} 
konfliktów społecznych, czego przykładem było Jezioro Czorsztyńskie, co do którego trwały spory, czy może ono stać się obszarem ciszy, z zakazem poruszania się po nim motorówek (Bernat, 2011).

\section{Podsumowanie}

Powstaje zatem zasadnicze pytanie, czy na tym etapie cywilizacyjnego (niedo)rozwoju możliwe jest jeszcze odzyskanie ciszy, spokoju, natury, zdominowanej przez antropogeniczne zanieczyszczenia? Świadomie posiłkuję się kategorią (niedo)rozwoju, gdyż skok cywilizacyjny, w wielu wymiarach okazał się dla człowieka katastrofą, regresem i cofaniem się, zamiast pójściem naprzód. Uzasadnienie znajduje tutaj sformułowana przez Régisa Debraya (2010) hipoteza postępu wstecznego, mówiąca o tym, iż postępowi technologicznemu zawsze towarzyszy regres w sferze mentalnej. Hałas miasta staje się dla ludzi tak nieznośny, że uciekają od niego do enklaw ciszy i spokoju ${ }^{25}$ (Szołtysek, Twaróg 2012; Renshav 2011), a antropogenicznie nieskażone tereny zaliczane są do jednych z najbardziej atrakcyjnych krajobrazowo. Coraz dobitniej mówi się o wzornictwie akustycznym jako świadomym planowaniu i kształtowaniu środowiska dźwiękowego (Losiak, 2017). Istotą tego projektowania jest eliminowanie dźwięków szkodliwych, nadmiarowych i przypadkowych. Ważnym aspektem tego typu działań jest także ochrona obszarów ciszy (Schafer, 1982), ciekawą tendencją może być wykorzystanie naturalnej energii wiatru lub wody (Skalski, 2008) w planowaniu przestrzennym. Podlegający procesom desensytyzacji człowiek nie potrafi już słuchać, a redundantne dźwięki, walczące o jego uwagę, jedynie intensyfikują i pogłębiają ten katastrofalny dla jego dobrostanu proces. Totalizująca hegemonia człowieka epoki antropocenu zagraża nie tylko samemu człowiekowi, ale i całemu ekologicznemu otoczeniu, w jakim funkcjonuje. O doświadczaniu krajobrazu decydują nie tylko jego wizualne atrybuty, ale także rzadziej zauważalne jego wymiary - dźwiękowe i zapachowe, które determinują jego odbiór. Pominięcie czynnika akustycznego ten odbiór spłaszcza i deformuje. Zogniskowanie naszej uwagi na konieczności ochrony ciszy pejzaży dźwiękowych, w niskim stopniu odpornych na antropogeniczną inwazję, staje się kluczowym wyzwaniem, z którym trzeba się zmierzyć.

\footnotetext{
${ }^{25} \mathrm{Z}$ badań wynika, że $11 \%$ mieszkańców wsi stanowią osoby, które przeniosły się tam z miasta (FedyszakRadziejowska, 2016). Główną motywacją takiej migracji jest komfort zamieszkania. Badanie CBOS z 2015 roku „Kto marzy o życiu na wsi, a kto o życiu w mieście?” pokazuje, iż wieś jest najbardziej preferowanym miejscem, jeśli chodzi o zamieszkanie (40\%), kolejno są to średniej wielkości miasta (22\%). Wieś kojarzona jest z wolniejszym tempem życia, harmonią i stabilizacją (50\%), przyrodą (41\%), ale także ciszą (23\%). Dla ponad połowy ankietowanych przeprowadzka z miasta na wieś stanowi wskaźnik sukcesu i awansu społecznego (56\%). Głównym argumentem, dla którego Polacy deklarują chęć zamieszkania na wsi, jest spokój (48\%), a aż $58 \%$ ankietowanych zapytanych o to, czy gdyby mogli wybrać sobie miejsce zamieszkania wskazuje wieś (Kowalczuk, 2015; Hipsz, 2014).
} 


\section{Bibliografia}

Abriszewski, K. (2008). Poznanie, zbiorowość, polityka: analiza teorii aktora-sieci Bruno Latoura. Kraków: Universitas.

Abriszewski, K. (2007). Teoria aktora-sieci Bruno Latoura. Teksty Drugie, 1-2, 113-126.

Abriszewski, K. (2010). Wszystko otwarte na nowo: teoria aktora-sieci i filozofia kultury. Torun: Wydawnictwo Naukowe Uniwersytetu Mikołaja Kopernika.

Amato, J. (2002). Rethinking home: a case for writing local history. Berkeley, Los Angeles: University of California.

Balon, J., Maciejowski, W. (2012). Geoekologia dla architektów krajobrazu. Kraków: Instytut Architektury Krajobrazu, Politechnika Krakowska.

Bańka, A. (2002). Społeczna psychologia środowiskowa. Warszawa: Scholar.

Baronsky, A. D., Matzke, N., Tomiya, S., Wogan, G. i in. (2011). Has the Earth's sixth mass extinction already arrived? Nature, 471, 51-57.

Bernat, S. (2007). Ochrona i zarządzanie krajobrazem dźwiękowym w regionach turystycznych. W:

A. Strzyż, A. Świercz (red.), Badania regionalne - wybrane problemy (s. 291-298). Kielce: Akademia Świętokrzyska Jan Kochanowskiego.

Bernat, S. (2010). Obszary ciche w aglomeracjach. W: M. Barwiński (red.), Obszary metropolitarne we współczesnym środowisku geograficznym (s. 305-314). 58. Zjazd Polskiego Towarzystwa Geograficznego, t.2, Oddział Łódzki PTG, Wydział Nauk Geograficznych, Łódź: Uniwersytet Łódzki.

Bernat, S. (2011). Krajobraz dźwiękowy jutra. Prace Komisji Krajobrazu Kulturowego, 15, 193205.

Bernat, S. (2013). Toponofilia. W poszukiwaniu harmonii krajobrazu dźwiękowego. Ethos, 4(104), 235-251.

Bernat, S. (2015). Wokół pojęcia soundscape. Dyskusja terminologiczna. Prace Komisji Krajobrazu Kulturowego, 30, 45-57.

Bernat, S. (2017). Terapeutyczne właściwości krajobrazu. W: S. Bernat (red.), Krajobraz a zdrowie (s. 33-51). Lublin: Uniwersytet Marii Curie-Skłodowskiej.

Bernat, S., Kałamucka W. (2008). The „landscape experienced” in empirical research conducted by Lublin scholars. Prace Komisji Krajobrazu Kulturowego, 8, 21-33.

Bińczyk, E. (2018). Epoka człowieka. Retoryka i marazm antropocenu. Warszawa: Wydawnictwo Naukowe PWN.

Boussalis, C., Coan, T. (2016). Text-mining the signals of climate change doubt. Global Environmental Change, 36, 89-100.

Braden, C. (2012). Acoustic tourism - an emerging industry. The Global Composition. Sound, Media and the Environment. Darmstadt-Dieburg. Pobrano z: www.blackicesound.com (16.09.2019). 
Carles, J. L., Barrio, I. L., de Lucio, J. V. (1999). Sound influence on landscape values. Landscape and Urban Planning, 43(4), 191-200.

Carter, L., Williams, W., Black, D., Bundy, E. (2014). The leisure-noise dilemma: hearing loss or hearsay? What does the literature tell us? Ear Hear, 35(5), 491-505.

Castree, N. (2014). The anthropocene and the environmental humanities. Environmental Humanities, 5, 233-260.

Csikszentmihalyi, M. (2005). Przeplyw. Psychologia optymalnego doświadczenia (M. WajdaKacmajor, tłum.). Taszów: Biblioteka Moderatora.

Chwalibóg, K., Wolski, P. (2015). To co ważne dla przeciwdziałania destrukcji krajobrazu. W: S. Ratajski, M. Ziółkowski (red.), Krajobraz kulturowo-przyrodniczy z perspektywy społecznej (s. 71-95). Warszawa: Narodowe Centrum Kultury.

Debord, G. (2006). Społeczeństwo spektaklu oraz Rozważania o społeczeństwie spektaklu (M. Kwaterko, thum.). Warszawa: Państwowy Instytut Wydawniczy.

Debray, R. (2010). Wprowadzenie do mediologii (A. Kapciak, thum.). Warszawa: Wydawnictwo Oficyna Naukowa.

Dobrzański, G., Dobrzańska, D., Kiełczewski, D. (1997). Ochrona środowiska przyrodniczego. Białystok: Wydawnictwo Ekonomia i Środowisko.

Domańska, E. (2008). Humanistyka nie-antropocentryczna a studia nad rzeczami. Kultura Wspótczesna, 3, 9-21.

Domańska, E. (2010). Beyond anthropocentrism in historical studies. Historein, 10, 118-130.

Domańska, E. (2013). Humanistyka ekologiczna. Teksty Drugie, 1-2, 13-32.

Dorn, S., Relf, D. (1995). Horticulture: Meeting the needs of special populations. Hort Technology, 5(2), 94-103.

Doughty, K. (2013). Walking together: The embodied and mobile production of therapeutic landscape. Health \& Place, 24, 140-146.

Dunlap, R. E. (2013). Climate change skepticism and denial: An introduction. American Behavioral Scientist, 57(6), 691-698.

EEA Report (2014). Noise in Europe 2014. Pobrano z: https://www.eea.europa.eu/publications/noise-in-europe-2014 (15.09.2019).

Fedyszak-Radziejowska, B. (2016). Społeczności wiejskie - stabilizacja procesu przemian. W: J. Wiklin, K. Nurzyńska (red.), Polska wieś 2016. Raport o stanie wsi (s. 63-80). Warszawa: SCHOLAR.

Feliksiak, M. (2016). Stan środowiska i zmiany klimatu. Komunikat CBOS, nr 36.

Gesler, W. (2005). Therapeutic landscapes: An evolving theme. Health and Place, 11, 295-297.

Gifford, R., Scannell, L., Kormos, Ch. i in. (2009). Temporal pessimism and spatial optimism in environmental assessments: An 18-nation study. Journal of Environmental Psychology, 29(1), $1-12$. 
Gołaszewska, M. (1997). Estetyka pięciu zmystów. Warszawa, Kraków: Wydawnictwo Naukowe PWN.

Gołąb, M. (2011). Muzyczna moderna w XX wieku. Między kontynuacja a zmiana fonosystemu. Wrocław: Uniwersytet Wrocławski.

Gwizdalanka, D. (1987). Strojenie trąb jerychońskich (cz. 3). Ruch Muzyczny, 21, 10-11.

Gwizdalanka, D. (1987a). Strojenie trąb jerychońskich (cz. 4). Ruch Muzyczny, 22, 22-23.

Gwizdalanka, D. (1995). Hałas, Lutosławski i cisza. Monchord, 8-9, 59-66.

Harley, A. (1995). Dźwięk i życie: narodziny ekologii dźwiękowej. Ruch Muzyczny, 6, 6-7.

Heidegger, M. (1977). Budować, mieszkać, myśleć. Warszawa: Czytelnik.

Hempton, G., Grossmann, J. G. (2009). One square inch of silence: One man's search for a natural silence in a noisy world. New York: Simon \& Schuster.

Hipsz, N. (2014). Wieś polska - stereotypy. Komunikat CBOS BS/4.

Humbolt, A. (1959). Podróże po Ameryce podzwrotnikowej (J. Babicz, J. Petryszyn, thum.). Warszawa: Książka i Wiedza.

Jacques, P. J., Dunlap, R., Freeman, M. (2008). The organisation of denial: Conservative think tanks and environmental scepticism. Environmental Politics, 17, 349-385.

Kapelański, M. (1999). Koncepcja „pejzażu dźwiękowego” (soundscape) w pismach R. Murraya Schafera. Praca magisterska przygotowana pod kierunkiem prof. M. Gołąba, w Instytucie Muzykologii Uniwersytetu Warszawskiego.

Kapelański, M. (2005). Narodziny i rozwój ekologii akustycznej pod banderą szkoły pejzażu dźwiękowego. Muzyka, 2, 107-119.

Kapuściński, R. (1990). Wojna futbolowa. Warszawa: Agora SA.

Kapuściński, R. (1997). Lapidarium III. Warszawa: Czytelnik.

Kapuściński, R. (2004). Podróże z Herodotem. Kraków: Znak.

Karjalainen, E., Sarjala, T., Raitio, H. (2010). Promoting human health through forests: overview and major challenges. Environmental Health and Preventive Medicine, 15, 1-8.

Kasprzak, M. (2014). Wielkomiejskie hałasy. W: R. Losiak, R. Tańczuk (red.), Audiosfera Wrocławia (s. 261-281). Wrocław: Wydawnictwo Uniwersytetu Wrocławskiego.

Keating, A. L., Merenda, K. (2013). Decentring the human? Towards a post-anthropocentric standpoint theory. Praktyka Teoretyczna, 10 (4), 65-86.

Kobierzycki, T. (2001). Filozofia osobowości. Warszawa: Eneteia.

Kolbert, E. (2014). Szóste wymieranie. Historia nienaturalna. Warszawa: Wydawnictwo W.A.B.

Kopczyński, K., Skoczylas, J. (2008). Krajobraz przyrodniczy i kulturowy. Próba ujęcia interdyscyplinarnego. Poznań: Uniwersytet im. Adama Mickiewicza.

Kowalczuk, K. (2015). Kto marzy o życiu na wsi, a kto o życiu w mieście? Komunikat CBOS, nr 18. 
Kryter, K.D. (1970). The effects of noise on man. Cambridge: Academic Press.

Kubicki, G. (1994). O myślistwie z perspektywy kanadyjskiej. Dzikie Życie, 3, 4-5.

Kulczyk, S. (2013). Krajobraz i turystyka: o wzajemnych relacjach. Warszawa: Uniwersytet Warszawski.

Latour, B. (2009). Polityka natury. Nauki wkraczaja do demokracji (A. Czarnacka, thum.). Warszawa: Wydawnictwo Krytyki Politycznej.

Latour, B. (2010). Splatając na nowo to, co społeczne: wprowadzenie do teorii aktora-sieci (A. Derra, K. Abriszewski, tłum.). Kraków: Universitas.

Leakey, R., Lewin, R. (1999). Szósta katastrofa (J. Prószyński, tłum.). Warszawa: Prószyński i Ska.

Leder, A. (2000). Po drugiej stronie duszy. Kto będzie zdrowy psychicznie? Polityka, 22, 72-73.

Leder, A. (2006). Głód Narcyza, czyli o uzależnieniu i ekscytacji. Niezbędnik Inteligenta (dodatek do Polityki nr 25), (9), 9-12.

Leśniowska-Matusiak, I., Wnuk, A. (2014). Wpływ hałasu komunikacyjnego na stan środowiska akustycznego człowieka. Transport Samochodowy, 3, 37-63.

Losiak, R. (2005). „Troska” i „beztroska” w przestrzeni fonosfery. Wokół aksjomatycznego i egzystencjalnego kontekstu „troskliwości”. W: R. Tańczuk, D. Wolska (red.), Aksjotyczne przestrzenie kultury (s. 82-90). Wrocław: Wydawnictwo Uniwersytetu Wrocławskiego.

Losiak, R. (2012). Pejzaż dźwiękowy lo-fi w przestrzeni fonicznej miasta. W: J. Harbanowicz, A. Janiak (red.), Przestrzeń zgiełku (s. 11-12). Wrocław: Wydawnictwo Naukowe Dolnośląskiej Szkoły Wyższej.

Losiak, R. (2015). Malowniczość pejzażu dźwiękowego. O pewnym aspekcie estetycznego doświadczenia audiosfery. Teksty Drugie, 5, 45-57.

Losiak, R. (2017). Wokół idei ekologii akustycznej. Koncepcje i praktyki. Studia Etnologiczne $i$ Antropologiczne, 17, 115-126.

Losiak, R., Tańczuk, R. (2014). Audiosfera Wrocławia. Wrocław: Wydawnictwo Uniwersytetu Wrocławskiego.

Makomaska, S. (2012). Audiomarketing - muzyka jako narzędzie ukrytej perswazji. W: J. Harbanowicz, A. Janiak (red.), Przestrzeń zgiełku (s. 236-245). Wrocław: Wydawnictwo Naukowe Dolnośląskiej Szkoły Wyższej.

Malm, A., Hornborg, A. (2014). The geology of mankind? A critique of the Anthropocene narrative. The Anthropocene Review, 1(1), 62-69.

Markiewicz, M. (2015). Przekroczyć człowieka. Uwagi o postantropocentrycznym problemie umiejscowienia. Anthropos?, 24, 110-119.

Miedema, H. M. E., Oudshoorn, C. G. M. (2001). Annoyance from transportation noise: relationships with exposure metrics DNL and DENL and their confidence intervals. Environmental Health Perspectives, 109(4), 409-416. 
Mitchell, W. J. (1994). Picture theory: Essays on verbal and visual representation. Chicago: University of Chicago Press.

Myga-Piątek, U. (2012). Krajobrazy kulturowe. Aspekty ewolucyjne i typologiczne. Katowice: Uniwersytet Śląski.

Myśliwski, G. (2000). Rola dźwięku w społecznościach tradycyjnych. W: H. Manikowska, A. Bartosiewicz, W. Falkowski (red.), Aetas media, aetas moderna. Studia ofiarowane prof. $H$. Samsonowicza $w$ siedemdziesiata rocznice urodzin (s. 682-698). Warszawa: Instytut Historyczny, Uniwersytet Warszawski.

Park, B. J., Tsunetsugu, Y., Kasetani, T., Kagawa, T, Miyazaki, Y. (2010). The psychological effects of Shirin-yoku (taking in the forest atmosphere or forest bathing): Evidence from field experiments in 24 forests across Japan. Environmental Health and Preventive Medicine, 15(1), $18-26$.

Pawlas, K. (2015). Hałas jako czynnik zanieczyszczający środowisko - aspekty medyczne. Medycyna Środowiskowa, 18(4), 49-56.

Pawłowska, K. (2002). Idea swojskości krajobrazu kulturowego. W: K. Pawłowska, M. Swaryczewska (red.), Ochrona dziedzictwa kulturowego: zarzadzanie $i$ partycypacja spoleczna (s. 95-102). Kraków: Wydawnictwo Uniwersytetu Jagiellońskiego.

Pietraszko, S. (1992). Studia o kulturze. Wrocław: AVA Publishers.

Pijanowski, B. C., Villanueva-Rivera, J., Dumyahn, S. L., Farina, A., Krause, B. L., Napoletano, B., Gage, S. H., Pieretti, N. (2011). Soundscape ecology: The science of sound in the landscape. BioScience, 61(3), 203-216.

Pociask-Karteczka, J. (2010). Czy istnieją granice ingerencji człowieka w środowisko przyrodnicze? W: Z. Krzan (red.), Nauka a zarzadzanie obszarem Tatr i ich otoczeniem (s. 1119). Zakopane: Tatrzański Park Narodowy, tom III.

Ponikowska, I., Marciniak, K. (1988). Ciechocinek - terenoterapia uzdrowiskowa. Warszawa: Państwowe Wydawnictwo Naukowe.

Powell, J. L. (2012). The inquisition of climate science. New York: Columbia University Press.

Prawo do ochrony środowiska, Dz. U. 2001.62.627, z dnia 20 czerwca 2001.

Renshav, N. (2011). Avoid, prevent \& reduce: The importance of vehicle noise standards. Brussels: STOA Workshop.

Rosa, H. (2003). Social acceleration: Ethnical and political consequences of a desynchronized high speed society. Constellations, 10, 3-33.

Rose, E. (2012). Encountering place: A psychoanalytic approach for understanding how therapeutic landscapes benefit health and wellbeing. Health \& Place, 18(6), 1381-1387.

Schafer, M. (1977). The tuning of the world. New York: Knopf.

Schafer, M. (1982). Muzyka środowiska (D. Gwizdalanka, thum.). Res Facta, 9, 298-315.

Schafer, M. (1995). Poznaj dźwięk. 100 ćwiczeń w stuchaniu i tworzeniu dźwięków (R. Augustyn, tłum.). Poznań: Brevis. 
Senetra, A., Szczepańska, A., Wasilewicz-Pszczółkowska, M. (2014). Traffic noise as a factor driving apartment prices: a case study of a large European urban agglomeration. Acoustics Australia, 42, 47-50.

Skalski, J. (2008). Wykorzystanie siły wody i wiatru do tworzenia kojących przestrzeni dźwiękowych w krajobrazie miasta. W: S. Bernat (red.), Dźwięk w krajobrazie jako przedmiot badań interdyscyplinarnych (s. 153-162). Lublin: Uniwersytet Marii Curie-Skłodowskiej, Prace Komisji Krajobrazu Kulturowego PTG.

Steffen, W., Broadgate, W., Deutsch, L., Gaffney, O. \& Ludwig, C. (2015). The trajectory of the Anthropocene: The great acceleration. The Anthropocene Review, 2(1), 81-98.

Stoner, A., Melathopoulos, A. (2015). Freedom in the Anthropocene: Twentieth-century helplessness in the face of climate change. London: Palgrave Macmillan.

Szołtysek, J., Twaróg, S. (2012). Problematyka hałasu we współczesnych miastach. Studia Miejskie, tom 6, 75-84.

Szostek, M. (2014). Postantropocentryzm, czyli rzecz o poszerzaniu granic wspólnoty. Przegląd Humanistyczny, 1(442), 7-14.

Szpunar, M. (2016). Humanistyka cyfrowa a socjologia cyfrowa. Nowy paradygmat badań naukowych. Zarzadzanie w Kulturze, 4, 355-369.

Szpunar, M. (2017). Emotywne aspekty recepcji muzycznej. Kultura Wspótczesna, 3, 68-77.

Szpunar, M. (2017a). Wrażliwość (nie tylko) artystyczna. Kultura i Społeczeństwo, 1, 123-134.

Szpunar, M. (2018). Kultura lęku (nie tylko) technologicznego. Kultura Wspótczesna, 2, 114-123.

Szpunar, M. (2018a). (Nie)potrzebna wrażliwość. Kraków: Instytut Dziennikarstwa, Mediów i Komunikacji Społecznej Uniwersytetu Jagiellońskiego.

Szpunar, M. 2019. Kwantyfikacja rzeczywistości. O nieznośnym imperatywie policzalności wszystkiego. Zeszyty Prasoznawcze, 3, 95-104.

Szpunar, M., Parus, M. (2017). Muzyka w kulturze. Kultura w muzyce. Kultura Wspótczesna, 3, 10-13.

Thompson, C. W. (2011). Linking landscape and health. The recurring theme. Landspace and Urban Planning, 99(3-4), 187-195.

Trojanowska, M. (2017). Parki i ogrody terapeutyczne. Warszawa: Wydawnictwo Naukowe PWN.

Tyburski, W. (2013). Dyscypliny humanistyczne i ekologia. Toruń: Wydawnictwo Naukowe Uniwersytetu Mikołaja Kopernika.

Ucho na świat. Wywiady Katarzyny i Krzysztofa Świdraków (2010). Warszawa: Carta Blanca.

Urry, J. (2007). Spojrzenie turysty (A. Szulżycka, tłum.). Warszawa: Wydawnictwo Naukowe PWN.

Van Vugt, M., Giskevicius, V., Schultz, P. (2014). Naturally green: Harnessing stone age psychological biases to foster environmental behavior. Social Issues and Policy Review, 8, 132. 
Wciórka, B. (2009). Zagrożenie hałasem - opinie z lat 1999 i 2009. Komunikat CBOS, BS/122/2009.

Welsch, W. (1997). Estetyka i anestetyka (M. Łukasiewicz, thum.). W: R. Nycz (red.), Postmodernizm. Antologia przekładów (s. 520-547). Kraków: Wydawnictwo Baran i Suszczyński.

Welsch, W. (2001). Na drodze do kultury słyszenia? (K. Wilkoszewska, tłum.). W: I. Wilk (red.), Przemoc ikoniczna czy „nowa widzialność”? (s. 56-74). Katowice: Wydawnictwo Uniwersytetu Śląskiego.

Westerkamp, H. (2015). Spacery dźwiękowe (K. Kijowska, tłum.). Glissando. Nr 26. Pobrano z: http://glissando.pl/tekst/spacery-dzwiekowe/ (18.09.2019).

Wilson, E. O. (1984). Biophilia: The human bond with other species. Cambridge: Harvard University Press.

Wojciechowski, K. H. (1986). Problemy percepcji i oceny estetycznej krajobrazu. Lublin: Uniwersytet Marii Curie-Skłodowskiej.

Wolf, K.L., Flora, K. (2010). Mental health and function: A literature review. W: Green cities: Good health. Washington: College of the Environment, University of Washington. Pobrano z: www.greenhealth.washington.edu (17.09.2019).

\title{
Ecology of the soundscape
}

\begin{abstract}
In this paper, the author argues that the key to understanding the condition of our contemporaries lies in how and what we hear. We tend to perceive culture and our social environment visually and, because of this dominant visual perspective, we consider hearing to be of secondary importance. That is why we need to contest such vision-centric hegemony limited to one sense only. The paper situates itself within soundscape studies - the field approaching sound as a significant resource of the environment, the fount of meanings and aesthetic experiences. Special attention has been given to transformations occurring in the soundscape, changing functions of sounds as well as the positive impact of landscape (including its soundscape) on people's mental wellbeing.
\end{abstract}

Keywords: sound landscape; Anthropocene; sound; soundscape studies; silence; noise; audiosphere; phonosphere

Magdalena Szpunar prof. nadzwyczajny, dr hab. nauk społecznych w zakresie socjologii, specjalizacja: nauki o mediach, medioznawstwo, socjologia internetu, nowe media. Pracuje w Instytucie Dziennikarstwa, Mediów i Komunikacji Społecznej Uniwersytetu Jagiellońskiego, gdzie kieruje Zakładem Nowych Mediów. Autorka monografii: Kultura algorytmów, (Nie)potrzebna wrażliwość, Kultura cyfrowego narcyzmu, Imperializm kulturowy internetu. Więcej o autorce: www.magdalenaszpunar.com 